\title{
Монгуш А.B. \\ Исследование влияния состава топлива на выход продуктов неполного сгорания углей при сжигании угля в экспериментальной печи с фильтром
}

Тувинский государственный университет

(Россия, Кьзыл)

doi:10.18411/spc-22-04-2018-02

idsp: 000001:spc-22-04-2018-02

Загазованность воздушного пространства является одной из важных проблем г. Кызыла. Качество угля и неэффективные технологии его сжигания в печах частного сектора, коммунальных котельных города сопровождаются высоким химическим недожогом и приводят к сильному загрязнению атмосферного воздуха продуктами неполного сгорания угля и серьёзным экологическим последствиям. Площадь частного сектора города составляет 17,5 км2, это более половины жилого фонда. Потенциал атмосферы региона наименее приспособлен к самоочищению, что способствует формированию серьёзных проблем для населения. Предварительная технологическая обработка в настоящее время отсутствует, не существует внедрённых разработок экологически чистых технологий сжигания твёрдых топлив на основе тувинских углей $[1,2,3]$. Поэтому исследования направленные для решения данной проблемы являются актуальными.

Объектами исследования являются угли, реализуемые с топливных складов г. Кызыла, такие как каа-хемский, элегестский, балахтинский уголь, межегейский окисленный уголь. Для исследований была сконструирована экспериментальная печь с фильтром для улавливания летучих загрязняющих вещества и сажи. Печь представляет собой Рис. 1. Печь с фильтром для улавливания летучих загрязняющих веществ и сажи металлический корпус прямоугольной формы $(\mathrm{h}=520 \mathrm{Mm})$, с гофрированной алюминиевой трубой ( $\mathrm{h}=580 \mathrm{mм}, \mathrm{d}=100 \mathrm{mм}$ ), снабжённой фильтром для улавливания (рис. 1.).

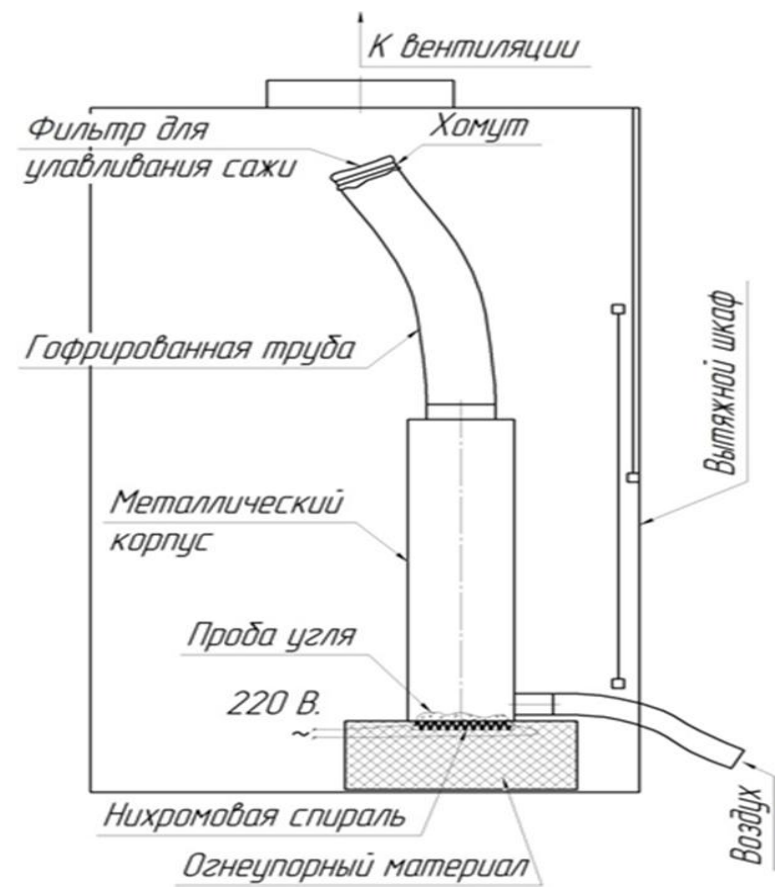

Из угольных образцовподбирались шихты (масса 10 г) различного состава с окисленными, некондиционными углями, например, шихты на основе каа-хемскогои межегейского окисленного угля в соотношении 1:1, 2:1, 4:1 для определения выхода загрязняющих летучих веществ, сажи, улавливаемых на фильтре и золы при их сжигании в экспериментальной печи. 
В таблице 1 представлены данные по выходу загрязняющих веществ и сажи, улавливаемых на фильтреи золы при сжигании угольнойшихты в соотношении 1:1.

Таблиияа 1

Выходы летучих веществ, сажи и золы при сжигании угольной шихты (1:1)

\begin{tabular}{|c|c|c|c|c|}
\hline Наименование & $\begin{array}{c}\text { Масса } \\
\text { летучих } \\
\text { веществ и } \\
\text { сажи, г }\end{array}$ & $\begin{array}{c}\text { Масса } \\
\text { золы, г }\end{array}$ & $\begin{array}{c}\text { Выход } \\
\text { летучих } \\
\text { веществ и } \\
\text { сажи, \% }\end{array}$ & $\begin{array}{c}\text { Время } \\
\text { сграния, } \\
\text { мин }\end{array}$ \\
\hline Каа-хемский: элегестский & 0,014 & 4,838 & 0,14 & 15 \\
\hline Каа-хемский: балахтинский & 0,004 & 2,625 & 0,04 & 13 \\
\hline $\begin{array}{c}\text { Каа-хемский: межегейский } \\
\text { окисленный }\end{array}$ & 0,026 & 3,382 & 0,26 & 12 \\
\hline
\end{tabular}

Наибольшим выходом загрязняющих летучих веществ и сажипри сжигании в печи с фильтром для улавливания характеризовался каа-хемский уголь. Наименьший выход загрязняющих веществ, улавливаемых на фильтре,был характерен для межегейского окисленного угля, масса летучих веществ и сажи составила 0,002 г.

Наименьший выход золы составил 2,466 г при сжигании шихты изкаа-хемского и балахтинского углей в соотношении 2:1, наибольший выход золы составил 4,835 г при сжигании шихты из каа-хемского и элегестского углей в соотношении 1:1.

На основании исследований получены новые данные показывающие экологические преимущества сжигания смесей углей с некондиционными углями. Данные о подобранных составах угольной шихты необходимы для разработки установки с бесконтактным нагревом угля.

$$
* * *
$$

1. Куликова М.П. Исследование физико-химических свойств улуг-хемских углей /Энергетик.-2014.-№ 8.-C.29-33.

2. Куликова М.П. Газоносность угольных пластов Улуг - Хемского бассейна./ Вестник ТувГУ. Естественные и сельскохозяйственные науки. Выпуск 29. 2016. С. 138-144.

3. К.К. Чульдум, М.П. Куликова. Обоснование принципиальной схемы установки для термохимической переработки углей./ Вестник ТувГУ, №2, 2017.-с.106-111.

\section{Сагар A.A. \\ Химический анализ поверхностных вод, отобранных в пределах межегейского угольного месторождения}

Тувинский государственный университет

(Россия, Кьзыьл)

doi:10.18411/spc-22-04-2018-03

idsp: 000001:spc-22-04-2018-03

В Туве основные запасы каменных углей сосредоточены в Улуг-Хемском угольном бассейне, общие ресурсы коксующихся углей оцениваются в 937 млн. тонн. Общая площадь бассейна порядка 2700 км2, в его пределах оценены 4 месторождения: Каа-Хемское, Межегейское, Элегесткое и Эрбекское [2].

С 1 сентября 2013 года ООО «УК Межегейуголь», принадлежащее «Евраз Холдинг», планирует вложить в разработку Межегейского месторождения каменного угля в Туве от 40 до 50 миллиардов рублей до 2030 года, сообщает республиканское министерство экономики. Проект 6 предусматривает строительство комплекса промышленных предприятий, которые должны обеспечить работу угольной шахты, получение конечной товарной продукции - концентрата и транспортировку. По информации Минэкономики, в настоящее время проводятся проектно-сметные работы [2]. 